\section{Reviewing Mini-lysimeter Controlled Irrigation in Container Crop Systems}

\author{
Dalyn McCauley ${ }^{1,2}$, Alexander Levin ${ }^{1,3}$, and Lloyd Nackley ${ }^{1,2}$
}

ADDITIONAL INDEX WORDS. crop water requirement, drainage, nursery, precision, water use

Summary. This study reviews how mini-lysimeters have been used effectively to optimize irrigation control in container horticulture production. Lysimeters are devices that measure evapotranspiration (ET) from the water balance of a fixed soil volume. The primary components of lysimeter-controlled irrigation are load cell sensors, a multiplexer, a data logger, a controller, and solenoid valves. The two common mini-lysimeter systems are platform lysimeters and suspension lysimeters. In these systems, a bending-beam single-point load cell is fastened between two plates, and a container is placed directly on the top platform. Platform lysimeters are commonly used for smaller pot sizes, and suspension lysimeters have been used for large shade trees up to $2.8 \mathrm{~m}$ tall and weighing $225 \mathrm{~kg}$. Mini-lysimeters have been used for decades to calibrate ET models and create on-demand irrigation control programs that replenish plant daily water use or maintain deficit conditions. Research has demonstrated that lysimeterbased irrigation can respond more effectively to seasonal and diurnal variations in water demand, increasing irrigation cycles when evaporative demand is high, and decreasing irrigation cycles when demand is low. A strength of these systems is that for containerized plants, such as nursery production systems, minilysimeters capture whole-plant water use, which presents a more holistic measure compared with soil moisture sensors or leaf moisture sensors.

$\mathrm{T}$ The development of more efficient irrigation technology for horticulture is important as available water becomes restricted (Food and Agriculture Organization of the United Nations, 2017), and

Received for publication 16 Feb. 2021. Accepted for publication 28 Apr. 2021

Published online 18 October 2021.

${ }^{1}$ Department of Horticulture, Oregon State University, Corvallis, OR, 97333

${ }^{2}$ North Willamette Research and Extension Center, Oregon State University, Aurora, OR, 97002

${ }^{3}$ Southern Oregon Research and Extension Center, Oregon State University, Central Point, OR, 97502

This paper is based on information presented during the "Using Sensors to Inform and Control Irrigation Research and Management" workshop during the American Society for Horticultural Science 2020 Virtual Conference.

We thank David Bryla for sharing photos, Melissa Scherr and Brent Warneke for their perspectives, the inspiring work by our fellow panelists at the Water Utilization and Management Professional Interest Group workshop, and the HortTechnology editorial staff.

This research was supported in part by The Oregon Department of Agriculture SCBG award ODA4190-GR.

L.N. is the corresponding author. E-mail: Lloyd.Nackley@Oregonstate.edu.

This is an open access article distributed under the CC BY-NC-ND license (https://creativecommons. org/licenses/by-nc-nd/4.0/).

https://doi.org/10.21273/HORTTECH04826-21 there is increasing regulation on nonpoint source pollution (Fulcher et al., 2016). Current irrigation strategies for nursery systems, including greenhouses, container nurseries, and fieldgrown nurseries, are based primarily on grower intuition and experience, and, consequently, crops are routinely overirrigated. Overirrigation increases pumping costs, plant susceptibility to pathogens (Lichtenberg et al., 2013), and nutrient leaching and contamination of surrounding waters (Fulcher et al., 2016). Irrigation scheduling for nursery crops is particularly complex because of the variety of species grown and differences in production systems, growing media, and delivery systems (Beeson, 2011). These factors all influence specific crop water requirements, making it impractical to determine a generalized irrigation solution. For these reasons, incorporating measurements of actual crop evapotranspiration $\left(\mathrm{ET}_{\mathrm{a}}\right)$ in irrigation control platforms is particularly important to optimize irrigation scheduling in nursery production systems (Beeson and Chen, 2018).

A robust method for determining $\mathrm{ET}_{\mathrm{a}}$ is using a lysimeter. Lysimeters are devices that calculate $\mathrm{ET}_{\mathrm{a}}$ from the water balance of a fixed soil volume. There are two primary types of lysimeters: weighing and nonweighing. Nonweighing lysimeters (often, drainage lysimeters) determine $\mathrm{ET}_{\mathrm{a}}$ indirectly by collecting a volume of water drained from the container and subtracting it from a known volume of water from irrigation and precipitation. The time it takes to accumulate a measurable volume of drainage reduces measurement resolution; therefore, $\mathrm{ET}_{\mathrm{a}}$ measurements from drainage lysimeters are only reliable when summed over weekly (or longer) periods (Allen et al., 2011). In contrast, weighing lysimeters measure $\mathrm{ET}_{\mathrm{a}}$ directly by the change in weight of the container and can provide accurate $\mathrm{ET}_{\mathrm{a}}$ data over periods as short as $30 \mathrm{~min}$ (Allen et al., 2011; Beeson, 2011).

Historically, lysimeters have been used in agronomic field crops. A field lysimeter should be installed in the middle of a uniform crop, $50 \mathrm{~m}$ from any edge, and filled with the same vegetation and soil type as the surrounding field (Allen et al., 2011). The measurements from the lysimeter are used to characterize $\mathrm{ET}_{\mathrm{a}}$ for the entire field to develop crop coefficients $\left(\mathrm{K}_{\mathrm{c}}\right)$ for irrigation scheduling (Fig. 1). To estimate ET for a specific crop $\left(\mathrm{ET}_{\mathrm{c}}\right)$ and growth stage, the reference ET $\left(\mathrm{ET}_{\mathrm{o}}\right)$ is multiplied by a crop coefficient $\left(\mathrm{ET}_{\mathrm{c}}=\mathrm{K}_{\mathrm{c}} \times\right.$ $\mathrm{ET}_{\mathrm{o}}$ ). The crop coefficient is a ratio between $\mathrm{ET}_{\mathrm{O}}$ and the measured $\mathrm{ET}_{\mathrm{a}}$ $\left[\mathrm{K}_{\mathrm{c}}=\mathrm{ET}_{\mathrm{a}} / \mathrm{ET}_{\mathrm{o}}\right.$ (Allen et al., 1998)]. Although weighing lysimeters have been a standard for calibrating ET models and developing crop coefficients for agronomic crops, lysimeter measurements of ET are sensitive to

\begin{tabular}{llll}
\hline $\begin{array}{l}\text { Units } \\
\text { To convert U.S. to SI, } \\
\text { multiply by }\end{array}$ & U.S. unit & SI unit & $\begin{array}{l}\text { To convert SI to U.S., } \\
\text { multiply by }\end{array}$ \\
\hline 0.3048 & $\mathrm{ft}$ & $\mathrm{m}$ & 3.2808 \\
3.7854 & $\mathrm{gal}$ & $\mathrm{L}$ & 0.2642 \\
2.54 & inch $(\mathrm{es})$ & $\mathrm{cm}$ & 0.3937 \\
0.4536 & $\mathrm{lb}$ & $\mathrm{kg}$ & 2.2046 \\
28.3495 & $\mathrm{Oz}$ & $\mathrm{g}$ & 0.0353 \\
$\left({ }^{\circ} \mathrm{F}-32\right) \div 1.8$ & ${ }^{\circ} \mathrm{F}$ & ${ }^{\circ} \mathrm{C}$ & $\left({ }^{\circ} \mathrm{C} \times 1.8\right)+32$
\end{tabular}




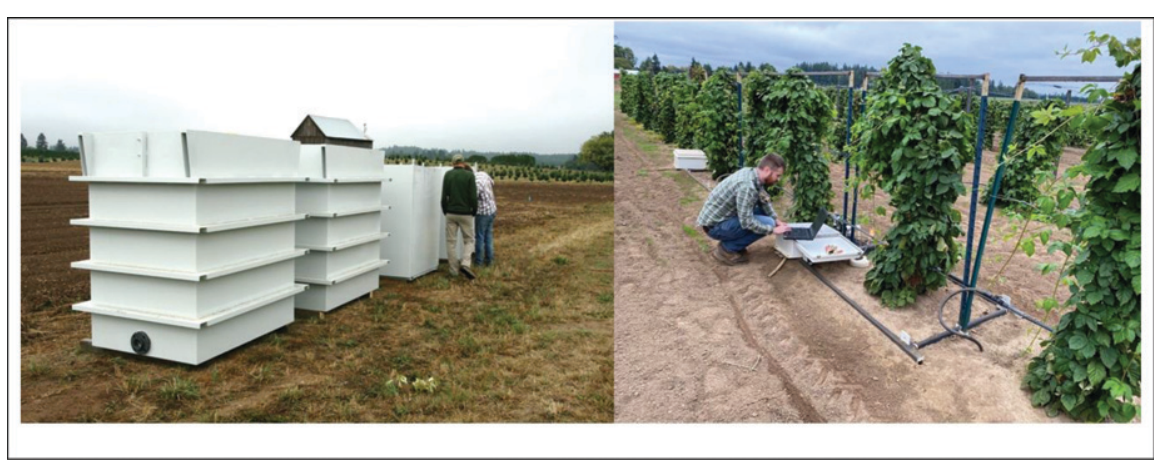

Fig. 1. The photos show examples of field-scale precision weighing lysimeters. The large white cubes (left) are inner and outer steel tanks for the lysimeters: $3.25 \mathrm{ft}$ wide $\times 5.0 \mathrm{ft}$ long $\times 5.5 \mathrm{ft}$ deep. These were installed under rows of trailing blackberry (right) at Oregon State University, North Willamette Research and Extension Center, Aurora, OR. $1 \mathrm{ft}=\mathbf{0 . 3 0 4 8} \mathrm{m}$. Photos courtesy of D. Bryla.

environmental factors and are prone to error. A review by Allen et al. (2011) indicated that potential sources of measurement error in field lysimeters are primarily the result of lysimeter containers being unrepresentative of the surrounding field conditions. Limitations include restricted rooting depth, disturbed soil within the container changing the soil hydraulic properties, increased container temperatures drying out the soil or causing condensation, and boundary effects on vegetation grown inside the lysimeter (Allen et al., 2011). As a result, ET values obtained from lysimeter measurements cannot always be scaled directly to represent large acreages. The potential sources of error associated with field lysimeters are less relevant in container production systems, such as nurseries and for some small fruit, where the objective is to measure the ET of a single container to inform irrigation scheduling directly for similar containers.

Lysimeters that have been scaled down for use with potted plants are often referred to as mini-lysimeters (Beeson, 2011; Shin and Son, 2015). Because mini-lysimeters provide a direct measure of container ET, they have the potential to be an effective tool for automatic irrigation scheduling in nursery systems. We present a review of the mini-lysimeter technology literature. Mini-lysimeter system designs, performance, and applications are discussed to assess the ability of mini-lysimeters to support a datadriven irrigation control system in production horticulture. The primary objectives of our study include detailing a mini-lysimeter system and the various design options for different specialty crops, highlighting the results from studies incorporating mini-lysimeters to research the soil-plant-atmosphere continuum, and synthesizing conclusions about lysimeter-based irrigation performance in nursery crops compared with traditional timer-based methods.

\section{Mini-lysimeter system design components}

A lysimeter-controlled irrigation loop system. In a closed-loop system, real-time information from the consequences of the previous action is used to evaluate and trigger the next system inputs. For lysimeter-controlled irrigation, this is done by using feedback from sensors that measure the change in weight of a container to inform the timing and duration of irrigation events. The primary components include load cell sensors, a multiplexer, a data logger, a controller, and solenoid valves.

LOAD CELL SENSOR. LOad cell sensors (or simply, load cells) are force transducers that convert force into an electrical signal. Load cells are differential analog sensors-meaning, the measurement is based on a voltage difference between two signal wires. The load cell output signal is directly proportional to the excitation voltage, so the output is expressed as the potential difference between the two signal wires per volt of excitation (millivolts per volt).

There are two common types of load cell configurations: four wire and six wire. Four-wire load cells contain two signal wires, an excitation wire, and a ground wire. Six-wire load cells system is a feedback-based, closed- have two extra sense wires that provide the actual voltage at the sensor itself. Six-wire load cells are considered more accurate because they can account for voltage drops between the power source and the sensor that may be caused by cable length or temperature effects.

DATA LOGgER AND MULTIPLEXER. The data logger houses the program for querying sensors and controlling irrigation valves. There are two primary options for data logger types: commercial (Beeson, 2011; Prehn et al., 2010; Shin and Son, 2015) or open-source platforms (Vera-Repullo et al., 2015). The major benefits of using commercial platforms are that they are more "plug and play," include technical support, and have higher quality components to increase accuracy. However, commercial platforms are more expensive, and the number of sensors that can be used in one data logger is limited by the number of differential analog channels (Bello and Van Rensburg, 2017). Open-source single-board computer platforms such as Arduino (Arduino, Ivrea, Italy) or Raspberry Pi (Raspberry Pi Foundation, Cambridge, UK) offer a low-cost option for monitoring and control applications. Open-source platforms are highly customizable and expandable. When interfacing analog load cells with open-source platforms, additional hardware is often necessary such as voltage regulators, amplifiers, signal filters, and analog-to-digital converters. Although individual components are often very cheap, there are high costs associated with the labor involved in building and troubleshooting open-source devices. For an additional cost, peripheral multiplexers can be used to increase the number of load cells that can be used on a data logger (Beeson, 2011). Multiplexers are mechanical relays that select between several input signals (analog or digital) and transmit data over a single output signal to the data logger.

CONTROLler AND SOLENOID valves. The data logger houses the program that queries sensors, processes information, and controls actions. However, data loggers often only supply small voltages $(3.3-5 \mathrm{~V})$ to peripheral devices, and it is common for solenoid valves that are used to control irrigation to require 12 to $24 \mathrm{~V}$ to operate. Because of this, a separate device is necessary to add 
control features to the system. This can be a commercial controller that can supply greater voltages to digital outputs, or a generic relay board that is used to convert a small electrical signal into movement or force. This actuation from relays can switch on a separate electrical circuit with a much greater voltage or current supply. This allows a $5-\mathrm{V}$ digital output from a data logger to control a higher voltage circuit, such as solenoid valves operating on a 24-V AC circuit.

\section{Types of mini-lysimeter systems}

Platform and SUsPension LYSIMETERS. The two common minilysimeter systems are platform lysimeters and suspension lysimeters. In these systems, a bending-beam singlepoint load cell is fastened in the center of the platform between two plates, and a container is placed directly on the top platform (Fig. 2). Bending-beam load cells are rated for both load capacity and the size of the platform area; as the load increases, so does the platform area. As such, there are space constraints for weighing heavier, larger containers. A potential solution for this is to replace the top-loaded system with a suspension lysimeter system. Suspension lysimeters weigh containers suspended from a tripod or frame by using an s-beam-type load cell that is best suited for tension loading scenarios.

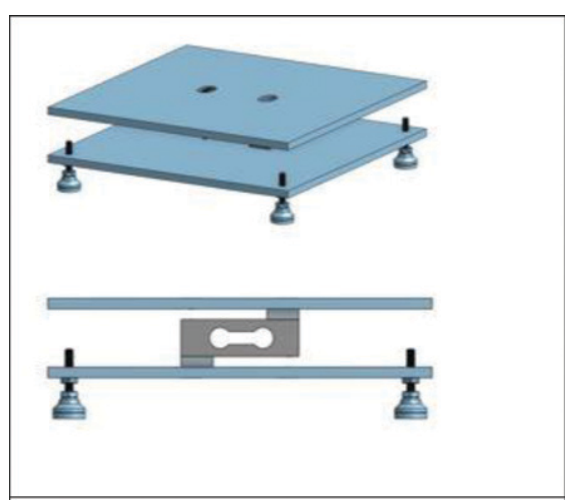

Fig. 2. An example of a mini-lysimeter assembly and load cell configuration with a bending-beam single-point load cell fastened between two plates. A container can be placed directly in the center of the top platform so the change in weight of the container reflects a direct measure of container evapotranspiration, assuming all other components of the water balance are known.
Beeson (2011) provides a detailed description of the mechanical components, program logic, and accuracy of suspension lysimeters designed for ornamental nursery crops. The Beeson system (Beeson, 2011) was designed to accommodate large shade trees up to $2.8 \mathrm{~m}$ tall and $225 \mathrm{~kg}$ in weight. A similar setup was used to monitor transpiration rates of soilless cucumber plants suspended from a greenhouse ceiling (Nikolaou et al., 2018), and also perennial flowers suspended from tripods (Beeson and Chen, 2018).

The change in weight of the container, either on a platform or suspended, is a direct measure of container ET, assuming all other components of the water balance are known. This assumption is reasonable during most periods during which ET is the only water flux in the system; however, it is not valid during periods of irrigation and drainage. As such, many lysimeter systems incorporate features for drainage collection and monitoring. This can be done with a pot-in-pot design in which the cultivated container is placed inside another pot that captures the drainage water (Prehn et al., 2010). Periodically, the volume of drainage water is measured and then emptied to calculate a water balance. Other systems incorporate a complete drainage monitoring subsystem by directing drainage from the cultivated container to a separate reservoir that is weighed by another load cell (Fields et al., 2020; Ruiz-Peñalver et al., 2015). This allows for highresolution, continuous monitoring of the container water balance during all periods. To increase the accuracy of ET during irrigation events, Shin and Son (2015) added another subsystem that captured and weighed the incoming irrigation. They used two s-beam load cells to suspend a large rectangular platform in a greenhouse, for which the measured weight was an aggregate of six plants on the platform. Two more s-beam load cells were used to suspend the irrigation and drainage tank below the plant platform.

Hydraulic Lysimeters AND MANUAL WEIGHING. For low-cost or low-resource applications, there are also lysimeter designs that do not require sophisticated data loggers and sensors, and rather use analog or manual methods to determine the change in weight of a container. Raphael et al. (2018) developed low-cost mini- hydraulic lysimeters to determine $\mathrm{ET}_{\mathrm{a}}$ of pepper (Capsicum chinense). $\mathrm{Hy}^{-}$ draulic lysimeters use a water-filled pipe placed under the loaded container in place of a load cell. A monometer is connected to the pipe to measure the change in pressure that is proportional to the load. Panda et al. (2014) used a similar low-cost hydraulic lysimeter to develop crop coefficients of chili pepper (Capsicum annumm). Hydraulic lysimeters can be a low-cost and lesstechnical solution that offers adequate accuracy over longer periods. However, they are often inaccurate for periods shorter than $24 \mathrm{~h}$ as a result of pressure variations from diurnal temperature changes (Allen et al., 2011).

For applications that do not require ET measurements over short periods, the change in weight of container plants can also be measured periodically and manually to inform irrigation. Dumroese et al. (2015) describe the methods to weigh about 120 plants/d manually to determine irrigation requirements. Manual measurements are achieved by attaching containers to hangers, like a hanging basket. Workers can easily hook the pots to a portable suspension scale and lift the plants to get a weight measurement and assess irrigation needs. Although manual weighing does not provide high-resolution, real-time data on crop water use, it is a good option for facilities that desire more informed crop water management but do not have the budget or resources to implement an automated lysimeter system.

\section{Considerations for system accuracy Calibration}

For robust calibration, load cell outputs should be characterized over a range of weights up to the rated capacity. Misra et al. (2011) tested three different calibration methods and found that a six-point calibration with loads increasing from zero to the load cell capacity, and subsequently decreasing back to zero, provided the best results. The loading and unloading of weights provide a test to assess hysteresis error in the load cell output (Bello and Van Rensburg, 2017). Calibration must be done after the load cell is mounted to the structure and after any cable extension so that the weight of the unloaded lysimeter and inherent voltage drops are accounted for in the calibration 
(Beeson, 2011; Ruiz-Peñalver et al., 2015). Bending-beam load cells are best suited for compression loading scenarios in which there is a single downward force in the center of a plate; therefore, they are sensitive to angular, twisting, or eccentric loading scenarios. For calibration of platform lysimeters, loads should be placed in the center of the weighing platform to minimize the mechanical advantage on the load cell, and placement should be consistent for lysimeter measurements to ensure accuracy and repeatability.

Data logger effects. The load cell output is also directly proportional to the excitation voltage, so there should be a consistent and known power source to load cells. An accurate voltage regulator or high-quality data logger should be used to ensure a reliable and consistent excitation voltage. The excitation voltage from a relay multiplexer is also known to deviate slightly. However, it was found that the measured load cell signal does not differ significantly under power-compensated conditions and that correction for multiplexer excitation voltage is not necessary (Misra et al., 2011; Ruiz-Peñalver et al., 2015).

Temperature efFects. Although load cells commonly include circuitry for temperature compensation, they can still be sensitive to temperature variations in the environment, especially if used outdoors. Load cells routinely exceed their specification for temperature sensitivity, deviating by as much as $5 \mathrm{~g} \cdot{ }^{\circ} \mathrm{C}^{-1}$. As such, the temperature sensitivity of individual load cells should be characterized and corrected for over the range of temperature expected (van Iersel et al., 2013). This is done by recording the response of the load cell signal to a range of temperatures while under constant load. The slope of the regression of recorded weight over air temperature is then used to correct for temperature error in the measurement.

This method has proved effective for correcting load cells (Bello and Van Rensburg, 2017), but other studies have also concluded that the thermal shift in the load cell signal from temperature effects is very small and unlikely to influence long-term lysimetric measurements (Misra et al., 2011). Therefore, the benefits of temperature correction depend on the lysimeter application. Temperature effects have a greater impact on measurements of ET over short periods $(<\mathrm{ld})$ or when the ET measurement is small, such as with newly planted propagules or seedlings (Beeson, 2011). Other methods to minimize the effects of temperature include painting the load cell body white to reduce the absorption of radiation, covering the structure in a white insulated box, or installing the load cells in-ground (Beeson, 2011).

\section{Applications of mini-lysimeter use in research Model calibration}

Mini-lysimeters provide a direct measurement of plant transpiration and soil evaporation over short intervals, and are commonly used as a tool to develop and validate crop water-use models for containerized crops. A goal for model validation is to correlate transpiration measurements, which can be costly or cumbersome to collect, with other environmental variables that are easier to measure, including air temperature, relative humidity, leaf temperature, solar radiation, and wind speed. For example, O'Meara et al. (2013) assessed the feasibility of using simple weather-based models to predict plant water use in greenhouse environments. They used mini-lysimeters to measure daily water loss from containers and monitored the weather variables within a greenhouse. They found that the daily water use of hydrangea (Hydrangea macrophylla) and gardenia (Gardenia jasminoides) was most influenced by the vapor pressure deficit and daily light integral.

Other transpiration models have been derived that are based on plant responses rather than environmental conditions. The FAO-56 PenmanMonteith model estimates ET based on temperature, wind speed, relative humidity, and solar radiation (Allen et al., 1998). Nikolaou et al. (2018) modified the Penman-Monteith model by substituting leaf temperature for vapor pressure deficit and solar radiation. The simplified leaf temperaturebased model was validated with a suspension lysimeter. Another study used mini-lysimeters to measure $\mathrm{ET}_{\mathrm{a}}$ and measurements of canopy area to develop a plant water-use model based on canopy area (Beeson and Chen, 2018).

Development of $\mathrm{K}_{\mathrm{c}}$ for agronomic crops has historically been done by using field lysimeters to measure $\mathrm{ET}_{\mathrm{a}}$ and micrometeorological instruments to measure the parameters necessary to calculate $\mathrm{ET}_{\mathrm{o}}$. Some studies have applied the same methodology by using mini-lysimeters to determine $K_{c}$ for nursery or greenhouse crops. Treder et al. (2017) used rectangular weighing mini-lysimeters to measure the $\mathrm{ET}_{\mathrm{a}}$ of six ornamental perennial species commonly grown in nurseries, and calculated an hourly $\mathrm{ET}_{\mathrm{o}}$ using the FAO-56 Penman-Monteith reference ET equation (Allen et al., 1998). O'Meara et al. (2013) calculated $\mathrm{K}_{\mathrm{c}}$ of perennial flowers by dividing the daily water use measured by mini-lysimeters inside a greenhouse by estimates of $\mathrm{ET}_{\mathrm{o}}$ from a weather station outside the greenhouse.

The high resolution of mini-lysimeters has also been used to study the variation of soilless substrates and the variation of plant phenotypes (Fig. 3). Fields et al. (2020) developed a system that measured evaporation and drainage simultaneously from a container of soil using two platform lysimeters. The two-platform setup determined the time for water to pass through peatand bark-based soils to improve a HYDRUS-3D, soil hydraulics, model. Last, commercial mini-lysimeters, such as the PlantArray system (Plant DiTech, Yavne, Israel), have been used in conjunction with soil and atmospheric probes to design a high-resolution, high-throughput diagnostic screening platform (Halperin et al., 2017).

\section{Irrigation control}

ON-DEMAND IRRIGATION CONTROL. On-demand irrigation refers to

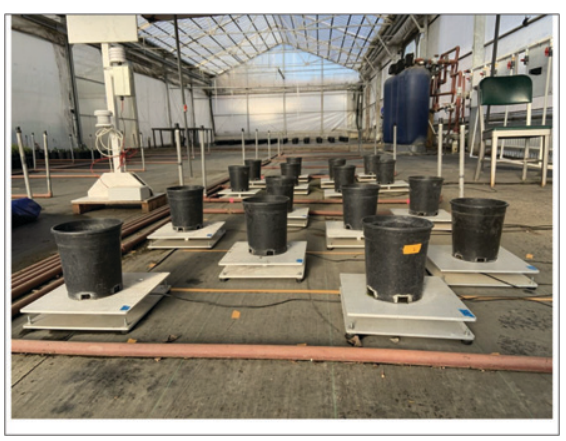

Fig. 3. An array of mini-lysimeters, with each stacked pair measuring $301 \mathrm{ft}=$ $0.3048 \mathrm{~m} .10 \mathrm{~cm}$. Nursery-trade 1 -gal nursery pots [volume, $0.71 \mathrm{gal}$ (2.688 L)] are used in a "dry-down" experiment in which groups of pot weights are averaged to control overhead irrigation in particular zones at specific thresholds. $1 \mathrm{~cm}=0.3937$ inch . 
autonomous irrigation control that aims to maintain a constant container weight. On-demand systems use lysimeter measurements to dictate both the timing and the volume of irrigation applied based on a predefined start and stop weight. For example, Prehn et al. (2010) used this method to maintain container weight to within $94 \%$ to $98 \%$ of saturation. To do this, they determined the weight setpoint by measuring the weight of a container at saturation. The on-demand irrigation was programmed to irrigate when the container reached $94 \%$ of the setpoint weight and ran until the substrate returned to $98 \%$ of the setpoint weight. Hunt and McDonald (2015) used a similar on-demand method in which irrigation was triggered when the container weight reached $85 \%$ of saturation, and irrigation continued until saturation was met again. Both studies found that the on-demand method was able to produce plants of marketable quality while using less water than traditional timer-based methods. The depletion thresholds in both studies were defined previously according to acceptable moisture content for the specific species and growing media, which is an important prerequisite for successful sensor-controlled irrigation control. A notable complication of using on-demand methods is that the setpoint weight must be redefined periodically to account for increases in plant biomass (Prehn et al., 2010). These periods depend on plant biomass accumulation rates that need to be known or estimated ahead of time.

REPLENISH DAILY WATER USE. Other lysimeter-controlled irrigation programs can be programmed to adjust for increases in plant biomass. Rather than irrigating automatically to maintain a constant container weight or water content, irrigation events can be programmed to occur on a fixed schedule and only replace the water lost since the last irrigation. This is done by measuring the container weight immediately before and after irrigation events to determine a precise volume of water to apply. O'Meara et al. (2013) used minilysimeters to calculate the plant daily water use by irrigating at night, when ET was considered negligible, and comparing pot weights at field capacity to pot weights the previous day. Any weight increases were attributed to plant growth. With this method, the starting weight is defined every day, and recalibration to account for plant biomass is not necessary if the increase in plant biomass over the course of the day is negligible (Shelford et al., 2004).

Beeson (2011) describes a similar method that used the cumulative ET over the course of a day to determine whether an irrigation event should occur and at what volume. If ET was greater than a predefined value, an irrigation event was triggered at midnight. The volume of the irrigation event was equal to the ET multiplied by an adjustment factor. The adjustment factor allows for a fractional increase or decrease in irrigation to be applied to account for different varieties or growth stages, as well as for nonuniform irrigation or drought stress applications. During times of high evaporative demand, a midday irrigation might be triggered as well to replace the ET lost from dawn to solar noon. This lysimeter-controlled irrigation method was used successfully to study the dynamics of plant-available water for containergrown woody shrubs (Beeson, 2006), to study the effect of canopy closure on $\mathrm{ET}_{\mathrm{o}}$ (Beeson, 2010), and to quantify daily water use for woody ornamentals (Beeson, 2007).

Deficit IRRIgATION. Minilysimeters were used to impose precision water stress and assess the drought responses of container-grown peach [Prunus persica (Wheeler et al., 2019)] and cherry [Prunus avium (Stott et al., 2019)]. In these studies, tree transpiration rates were calculated every $30 \mathrm{~min}$. Summing these incremental changes at midnight provided a cumulative transpiration total that was used as a metric to control irrigation timing. Trees were irrigated when daily cumulative transpiration decreased to less than a preprogrammed threshold that represented an approximate $80 \%$ decline from peak transpiration rates. This threshold was selected because it was associated with visible leaf wilt. This method of using a reduction in transpiration rate as an irrigation trigger allows for precise control of container water status based on the plant's physiological response to drought.

\section{Improved irrigation efficiency}

A limited number of studies have evaluated the performance of lysimeter- controlled irrigation systems compared with traditional timer-based or weather-based irrigation scheduling. Most studies conclude that lysimetercontrolled irrigation conserves water while producing plants similar in size and quality to those grown with timerbased irrigation (Table 1 ).

As described previously, Hunt and McDonald (2015) compared a lysimeter-controlled system to a timer-based and an ET-based irrigation control system. They found that the lysimeter system used 29\% less water than ET-based irrigation, and $42 \%$ less water than the timer-based irrigation with similar plant size and quality. Leaf area, growth rates, and marketability of orange jasmine ( $M u r$ raya paniculata) grown with lysimeter-controlled irrigation were not significantly different from the plants grown with timer-based irrigation. However, in a destructive harvest, plant biomass after 1 year was compared with seedling weight at the beginning of the study. They found the total increase in plant dry weight was greater with timer-based irrigation, indicating that more water from the timer-based method produced plants with a greater overall annual growth rate.

In a similar study, Prehn et al. (2010) compared a lysimeter-controlled system and a timer-based system and found there was no difference in the total water use across the season, but the lysimeter-controlled irrigation system was able to match more effectively the seasonal and diurnal variations in plant water demand. When ET was low, the lysimeter-based irrigation system used $79 \%$ less water daily than the timerbased method. However, when ET was at its peak, the lysimeter-controlled system tracked the increased demand and applied $20 \%$ more water than the timer-based system. Despite differences in applied water volume throughout the season, bearberry cotoneaster (Cotoneaster dammerii) grown with mini-lysimeters had equal biomass compared with the timer-based irrigation (Prehn et al., 2010). They also documented a significant difference in the volume of leachate between the two treatments. The on-demand lysimeter-based system resulted in a leaching fraction of $6 \%$ compared with a prescribed $20 \%$ for the timer-based irrigation. The reduction in leaching fraction 
Table 1. A list of the studies highlights the various of research applications and crops for which mini-lysimeters have been used in horticultural production systems; there are many other examples for which mini-lysimeters have also been used for nonhorticultural production systems.

\begin{tabular}{|c|c|c|c|}
\hline Research application & Crop & Environment & Citation \\
\hline Crop coefficients & Ornamentals & Nursery & Treder et al. (2017) \\
\hline Crop coefficients & Grapevine (Vitus sp.) & Field & Johnson et al. (2005) \\
\hline Crop coefficients & Multiple vegetables & Field & Bryla et al. (2010) \\
\hline Irrigation scheduling & Paprika (Capsicum sp.) & Greenhouse & Shin and Son $(2015)$ \\
\hline Irrigation scheduling & Woody perennials & Nursery & Hunt and McDonald (2015) \\
\hline Irrigation scheduling & Tomato (Solanum lycopersicum) & Greenhouse & Shelford et al. (2004) \\
\hline $\begin{array}{l}\text { Lysimeter design and performance } \\
\text { (calibration) }\end{array}$ & Wheat (Triticum sp.) & Greenhouse & Misra et al. (2011) \\
\hline $\begin{array}{l}\text { Lysimeter design and performance } \\
\text { (mechanics) }\end{array}$ & Multiple vegetables & Field & Nicolás-Cuevas et al. (2020) \\
\hline $\begin{array}{l}\text { Lysimeter design and performance } \\
\text { (mechanics) }\end{array}$ & Grapevine & Greenhouse & Ruiz-Peñalver et al. (2015) \\
\hline Plant phenotyping & Tomato & Greenhouse & Halperin et al. (2017) \\
\hline Precision drought & Cherry (Prunus avium) & Greenhouse & Stott et al. (2019) \\
\hline Precision drought & Peach (Prunus persica) & Greenhouse & Wheeler et al. (2019) \\
\hline Soil hydraulics & None & Greenhouse & Fields et al. (2020) \\
\hline Soil hydraulics & Date palm (Pheonix dactylifera) & Field & Tripler et al. (2012) \\
\hline Transpiration model calibration & Ornamentals & Greenhouse & Beeson and Chen (2018) \\
\hline Transpiration model calibration & Cucumber (Cucumis sativus) & Greenhouse & Nikolaou et al. (2018) \\
\hline Transpiration model calibration & Ornamentals & Greenhouse & O'Meara et al. (2013) \\
\hline
\end{tabular}

resulted in greater concentrations of phosphorus and potassium in the plant shoots; however, there were no significant differences in nitrogen concentration between the treatments. This indicates lysimeter-based irrigation was able to retain more nutrients for uptake by the plants.

Lysimeter-based irrigation systems were also able to respond more effectively to diurnal variability in ET demand. Prehn et al. (2010) found that as ET demand increased during the peak of the season, the number of irrigation cycles performed by the lysimeter system increased to as much as seven times per day, and the first irrigation event was initiated earlier in the day. This result was consistent with other studies that observed when evaporative demand was low (such as during rain); lysimeter-controlled irrigation events only occurred once every 2 to $3 \mathrm{~d}$ compared with a preprogrammed twicedaily schedule (Hunt and McDonald, 2015). A shift in irrigation in response to weather indicates that on-demand lysimeter-based irrigation can match real-time plant water demand.

\section{Conclusion}

Mini-lysimeters used in nursery and greenhouse crops have become powerful tools for measuring $\mathrm{ET}_{\mathrm{a}}$ of container plants accurately, calibrating crop models, assessing plant physiological traits, and using water resources efficiently. When lysimetercontrolled irrigation systems are compared with more traditional methods, they reduce water use and nutrient leaching, and can produce plants of the same quality. Because lysimeters measure ET over short periods, they can inform more sophisticated irrigation scheduling, such as applying precision water deficits. On-demand lysimeter-based irrigation can respond more effectively to seasonal and diurnal variations in water demand, increasing irrigation cycles when evaporative demand is high, and decreasing irrigation cycles when evaporative demand is low. For these reasons, lysimeter-controlled irrigation technology is an effective solution for the container nursery industry in a waterlimited future. However, there is limited research that evaluates the economic feasibility of using minilysimeters to control irrigation in production nursery environments.

For mini-lysimeter technology to extend beyond research and become prevalent in commercial nurseries, more research needs to be done to answer questions that are pertinent to growers and water managers. Factors such as scalability, affordability, and ease of use are important aspects that dictate the adoption and use of any technology by growers. For example, the number of lysimeters needed in a single irrigation zone to represent spatial variability accurately needs to be assessed. Costs of capital investment, maintenance, and labor associated with deploying lysimeter-controlled irrigation need to be weighed against potential savings from a reduction in water use, nutrient leaching, and pumping costs. Efforts should be made to develop user-friendly software so that growers can customize and troubleshoot an irrigation program. These are important gaps in the knowledge base that should be addressed to facilitate the adoption 
of lysimeter-based and other sensorbased irrigation technologies in production nurseries.

\section{Literature cited}

Allen, R.G., L.S. Pereira, T.A. Howell, and M.E. Jensen. 2011. Evapotranspiration information reporting: Factors governing measurement accuracy. Agr. Water Mgt. 98:899-920, doi: https://doi.org/ 10.1016/j.agwat.2010.12.015.

Allen, R.G., L.S. Pereira, D. Raes, and M. Smith. 1998. FAO irrigation drainage. Paper no. 56. Food and Agriculture Organization of the United Nations, Rome, Italy.

Beeson, R.C. 2006. Relationship of plant growth and actual evapotranspiration to irrigation frequency based on management allowed deficits for container nursery stock. J. Amer. Soc. Hort. Sci. 131:140-148, doi: https://doi.org/10.21273/JASHS.131. 1.140 .

Beeson, R.C. 2007. Determining plantavailable water of woody ornamentals in containers in situ during production. HortScience 42:1700-1704, doi: https:// doi.org/10.21273/HORTSCI.42.7.1700.

Beeson, R.C. 2010. Response of evapotranspiration of Viburnum odoratissimum to canopy closure and the implications for water conservation during production and in landscapes. HortScience 45:359-364, doi: https://doi.org/10.21273/HORT SCI.45.3.359.

Beeson, R.C. 2011. Weighing lysimeter systems for quantifying water use and studies of controlled water stress for crops grown in low bulk density substrates. Agr. Water Mgt. 98:967-976, doi: https:// doi.org/10.1016/j.agwat.2011.01.005.

Beeson, R. and J. Chen. 2018. Quantification of daily water requirements of container-grown Calathea and Stromanthe produced in a shaded greenhouse. Water 10:1194, doi: https://doi.org/10.3390/ w10091194.

Bello, Z.A. and L.D. Van Rensburg. 2017. Development, calibration and testing of a low-cost small lysimeter for monitoring evaporation and transpiration. Irr. Drain. 66:263-272, doi: https://doi. org/10.1002/ird.2095.

Bryla, D.R., T.J. Trout, and J.E. Ayars. 2010. Weighing lysimeters for developing crop coefficients and efficient irrigation practices for vegetable crops. HortScience 45:1597-1604, doi: https://doi.org/ 10.21273/HORTSCI.45.11.1597.

Dumroese, R.K., J.R. Pinto, and M.E. Montville. 2015. Using container weights to determine irrigation needs: A simple method. Native Plants J. 16:67-71, doi: https://doi.org/10.3368/npj.16.1.67.

Fields, J.S., J.S. Owen, R.D. Stewart, J.L. Heitman, and J. Caron. 2020. Modeling water fluxes through containerized soilless substrates using HYDRUS. Vadose Zone J. 19:e20031, doi: https://doi.org/ $10.1002 / \mathrm{vzj} 2.20031$.

Food and Agriculture Organization of the United Nations. 2017. The future of food and agriculture: Trends and challenges. Food and Agriculture Organization of the United Nations, Rome, Italy.

Fulcher, A., A.V. LeBude, J.S. Owen, S.A. White, and R.C. Beeson. 2016. The next ten years: Strategic vision of water resources for nursery producers. HortTechnology 26:121-132, doi: https://doi.org/ 10.21273/HORTTECH.26.2.121.

Halperin, O., A. Gebremedhin, R. Wallach, and M. Moshelion. 2017. Highthroughput physiological phenotyping and screening system for the characterization of plant-environment interactions. Plant J. 89:839-850, doi: https://doi. org/10.1111/tpj.13425.

Hunt, D.S. and J. McDonald. 2015. Automating irrigation scheduling in production nurseries using a weight-based irrigation controller. Acta Hort. 1104:49-56, doi: https://doi.org/10.17660/ActaHortic. 2015.1104.8.

Johnson, R.S., L.E. Williams, J.E. Ayars, and T.J. Trout. 2005. Weighing lysimeters aid study of water relations in tree and vine crops. Calif. Agr. 59(2):133-136.

Lichtenberg, E., J. Majsztrik, and M. Saavoss. 2013. Profitability of sensor-based irrigation in greenhouse and nursery crops. HortTechnology 23:770-774, doi: https://doi.org/10.21273/HORTTECH. 23.6.770.

Misra, R.K., J. Padhi, and J.O. Payero. 2011. A calibration procedure for load cells to improve accuracy of mini-lysimeters in monitoring evapotranspiration. J. Hydrol. 406:113-118, doi: https://doi.org/ 10.1016/j.jhydrol.2011.06.009.

Nicolás-Cuevas, J.A., D. Parras-Burgos, M. Soler-Méndez, A. Ruiz-Canales, and J.M. Molina-Martínez. 2020. Removable weighing lysimeter for use in horticultural crops. Appl. Sci. 10:4865, doi: https:// doi.org/10.3390/appl0144865.

Nikolaou, G., D. Neocleous, and N.K. Constantinos. 2018. Modelling transpiration of soilless greenhouse cucumber and its relationship with leaf temperature in a Mediterranean climate. Emir. J. Food Agr. 29:911-920, doi: https://doi.org/ 10.9755/ejfa.2017.v29.i12.1561.
O'Meara, L., M.W. van Iersel, and M.R. Chappell. 2013. Modeling daily water use of Hydrangea macrophylla and Gardenia jasminoides as affected by environmental conditions. HortScience 48:1040-1046, doi: https://doi.org/10.21273/HORT SCI.48.8.1040.

Panda, R.K., S. Patra, and D. Halder. 2014. Low cost PVC hydraulic weighing lysimeter for measurement of crop evapotranspiration. Acta Hort. 1015:317-324, doi: https://doi.org/10.17660/Acta Hortic.2014.1015.34.

Prehn, A.E., J.S. Owen, S.L. Warren, T.E. Bilderback, and J.P. Albano. 2010. Comparison of water management in container-grown nursery crops using leaching fraction or weight-based on demand irrigation control. J. Environ. Hort. 2:117123.

Raphael, O.D., K. Ogedengbe, J.T. Fasinmirin, D. Okunade, I. Akande, and A. Gbadamosi. 2018. Growth-stage-specific crop coefficient and consumptive use of Capsicum chinense using hydraulic weighing lysimeter. Agr. Water Mgt. 203:179-185, doi: https://doi.org/10.1016/j.agwat. 2018.03.011

Ruiz-Peñalver, L., J.A. Vera-Repullo, M. Jiménez-Buendía, I. Guzmán, and J.M. Molina-Martínez. 2015. Development of an innovative low cost weighing lysimeter for potted plants: Application in lysimetric stations. Agr. Water Mgt. 151:103-113, doi: https://doi.org/10.1016/j.agwat. 2014.09.020.

Shelford, T.J., A.K. Lau, and S.T. Chieng. 2004. Comparison of a new plant-based irrigation control method with lightbased irrigation control for greenhouse tomato production. Can. Biosys. Eng. 46: 1.1-1.6.

Shin, J.H. and J.E. Son. 2015. Development of a real-time irrigation control system considering transpiration, substrate electrical conductivity, and drainage rate of nutrient solutions in soilless culture of paprika (Capsicum annumm L.). Eur. J. Hort. Sci. 80:271-279, doi: https://doi. org/10.17660/eJHS.2015/80.6.2.

Stott, L.V., B. Black, and B. Bugbee. 2019. Differences in drought tolerance among Gisela ${ }^{\circledR}$ cherry rootstocks determined using automated weighing lysimeters. HortScience 54:1847-1852, doi: https://doi.org/ 10.21273/HORTSCI14267-19.

Treder, J., W. Treder, and K. Klamkowski. 2017. Determination of irrigation requirements and crop coefficients using weighing lysimeters in perennial plants. Infrastructure Ecol. Rural Areas 3:1213-1228, doi: https://doi.org/10.14597/infraeco. 2017.3.2.093. 
Tripler, E., U. Shani, A. Ben-Gal, and Y. Mualem. 2012. Apparent steady state conditions in high resolution weighingdrainage lysimeters containing date palms grown under different salinities. Agr. Water Mgt. 107:66-73, doi: https://doi. org/10.1016/j.agwat.2012.01.010.

van Iersel, M.W., M. Chappell, and J.D. Lea-Cox. 2013. Sensors for improved efficiency of irrigation in greenhouse and nursery production. HortTechnology 23: 735-746, doi: https://doi.org/10.21273/ HORTTECH.23.6.735.

Vera-Repullo, J.A., L. Ruiz-Peñalver, M. Jiménez-Buendía, J.J. Rosillo, and J.M. Molina-Martínez. 2015. Software for the automatic control of irrigation using weighing-drainage lysimeters. Agr. Water
Mgt. 151:4-12, doi: https://doi.org/ 10.1016/j.agwat.2014.10.021.

Wheeler, W., R. Wytsalucy, B. Black, G. Cardon, and B. Bugbee. 2019. Drought tolerance of Navajo and Lovell peach trees: Precision water stress using automated weighing lysimeters. HortScience 54: 799-803, doi: https://doi.org/10.21273/ HORTSCII3806-18. 